\title{
Securing Human Right to Water through Public Procurement in Slovakia ${ }^{1}$
}

\author{
Adam Máčaj \\ Comenius University in Bratislava, Slovakia \\ adam.macaj@flaw.uniba.sk.
}

MÁČAJ, Adam. Securing Human Right to Water through Public Procurement in Slovakia. International and Comparative Law Review, 2020, vol. 20, no. 2, pp. 254-273. DOI: 10.2478/iclr-2020-0028,

\begin{abstract}
Summary: The paper aims firstly to assess the deficiencies in access to drinking water that are present in Slovakia. Recently, the country was condemned for various violations in ensuring access to drinking water for all, whether by third parties, but also national institutions and international organizations. Drawing upon the identified failures and violations, the actions undertaken to remedy the situation are analysed, especially in order to establish whether Slovakia dispenses with its obligations under the human right to water and addresses the identified problems satisfactorily. Finally, the process of public procurement in providing drinking water is considered, having regard to its role in promptness and efficiency of addressing the unsatisfactory situation which makes Slovakia open to severe criticism from international human rights bodies.
\end{abstract}

Keywords: right to water, public procurement, social aspects, human rights, municipality, Slovakia.

\section{Introduction}

Access to water, and obstacles thereto, may be assessed through a variety of approaches, leading to different findings and conclusions even on similar factual basis. In the case of Slovakia, the regional differences in access to water and its uneven distribution are well-recognized, at least when having regard to climatic and geological conditions. ${ }^{2}$ However, the approach focusing on legal aspects and human rights-oriented views on access to water are nowadays similarly attracting attention among lawyers and institutions, as well as international community (see part 2). The stakeholders see inequalities as stemming not only from conditions or location of water sources, but also affected by conduct of public bodies, or their omissions. Even globally, the water crisis is argued to originate

1 This paper was prepared as part of the research project APVV-17-0641 "Improvement of effectiveness of legal regulation of public procurement and its application within EU law context".

2 See e. g. ZELEŇÁKOVÁ, Martina, FENDEKOVÁ, Miriam. Key Facts About Water Resources in Slovakia. In: NEGM, Abdelazim M, ZELEŇÁKOVÁ, Martina. (eds). Water Resources in Slovakia: Part I. Cham: Springer International Publishing, 2018. 
predominantly from governance failures, not its natural scarcity. ${ }^{3}$ Taking into account such factors, this paper aims to establish the presence of such disproportionate, structural inequalities in safeguarding right to water among vulnerable Roma communities in Slovak context, and assess whether situation complies with international human rights standards in this regard.

Secondly, the paper seeks to ascertain the situation of Roma communities lacking access to water in Slovakia, consider the difficulties implementation of right to water faces, and assess the various routes of criticism that arised as regards its protection (see part 3). Should the ongoing situation prove in violation of international standards, this paper finally aims to assess the projects aimed at tackling the situation and especially the role public procurement exerted on the situation (see part 4). Overall, this seeks to provide insight into the question whether public procurement can impact enjoyment of human rights through filling the current gaps of water distribution framework among vulnerable ethnic minority communities. While the implementation of social aspects in public procurement is done frequently to promote employment of vulnerable groups ${ }^{4}$ the assumption to be tested is that the procurement in Slovakia has not tackled the root causes hampering enjoyment of right to water, even where social aspects were deployed to the benefit of vulnerable groups.

\section{International recognition of right to water and its normative content}

Right to water as a distinct human right that requires separate set of safeguards to guarantee its full enjoyment for individuals has been emerging in international human rights law for a considerable period of time. The approach taken in absence of explicit recognition of such right in international human rights treaties relied on reading access to water and related safeguards into other substantive human rights provisions, ${ }^{5}$ an approach that persists among international human rights bodies even nowadays, ${ }^{6}$ when right to water has been regarded as separate human right at least since 2002 . This recognition was awarded predominantly by the general comment of the United Nations Committee on Economic, Social and Cultural Rights (hereinafter "UN CESCR"), one of the most significant turning points in this regard. ${ }^{7}$

3 WILDER, Margaret, INGRAM, Helen. Knowing Equity When We See It: Water Equity in Contemporary Global Contexts. In: CONCA, Ken, WEINTHAL, Erika (eds) The Oxford Handbook of Water Politics and Policy. New York: Oxford University Press, 2016.

4 MONTALBÁN-DOMINGO, Laura, GARCÍA-SEGURA, Tatiana, SANZ, Amalia, PELLICER, Eugenio. Social sustainability criteria in public-work procurement: An international perspective. Journal of Cleaner Production 2018, vol. 198, p. 1366.

5 BRAIG, Katharina Franziska. The European Court of Human Rights and the right to clean water and sanitation. Water Policy, 2018, vol. 20, no. 2, pp. 285-286.

6 See, among other authorities, ECtHR, Hudorovič and others v. Slovenia, app. nos. 24816/14 and 25140/14, 10 March 2020, $\$ 116$.

7 UN CESCR, General Comment No. 15 (2002) The right to water (arts. 11 and 12 of the International Covenant on Economic, Social and Cultural Rights), E/C.12/2002/11 (2002). 
The UN CESCR ascertained right to water as separate from those enumerated in the international human rights treaties, although the approach up until 2002 regarded water as object of protection of those substantive provisions. The UN CESCR in fact relied on right to water being a vehicle necessary for protection of multiple other human rights. Therefore, it derived the autonomous right to water from right to adequate housing, and right to highest attainable standard of health, while formerly, water was regarded as merely one of components essential for protection of those rights themselves. The process of deriving right to water as autonomous right by the UN CESCR therefore followed the proposal for inferring it from other substantive provisions of international human rights law. ${ }^{8}$

Such shift in narrative eventually persisted even in the recognition of autonomous right to water by the United Nations General Assembly (hereinafter "UN GA"). ${ }^{9}$ On the other hand, some authorities remained consistent in identifying right to water "characterized as an extension of existing rights" ${ }^{10}$ This approach persists in the jurisprudence of the European Court of Human Rights (hereinafter "ECtHR"), which relied on object and purpose, teleological approach, and doctrine of "living instrument" to read aspects of human rights protection not enshrined in the wording of the European Convention on Human Rights (hereinafter "ECHR"), ${ }^{11}$ and the result therefore similarly recognizes that water is an essential resource that may interfere with human rights rights, and triggers obligations of states, ${ }^{12}$ although it stops shy of calling right to water an independent human right. The approach deriving right to water only from its dependent rights, those explicitly recognized in the ICESCR, nevertheless retains traction, as even the language of General Comment No. 15 is not without ambiguity and the differences of approach led even to suggestions that right to water under contemporary international human rights law has a unique character, distinct from both independent, as well as derivative rights. ${ }^{13}$

The reasons why General Comment No. 15 departed from the common approach towards right to water as derivative are not explicitly recognized.

8 Cf. MCCAFFREY, Stephen. A Human Right to Water: Domestic and International Implications. Georgetown International Environmental Law Review. 1992, vol. 5, no. 1, p. 7.

9 UN GA, The human right to water and sanitation, G. A. Res. 64/29, 28 July 2010.

10 DE CHAZOURNES, Laurence Boisson. Fresh Water in International Law. Oxford: Oxford University Press, 2013, p. 150.

11 Cf. SCOTT, Craig. Interdependence and Permeability of Human Rights Norms: Towards a Partial Fusion of the International Covenants on Towards a Partial Fusion of the International Covenants on Human Rights Human Rights. Osgoode Hall Law Journal. 1989, vol. 27, no. 3, p. 809.

12 ECtHR, Hudorovič and others v. Slovenia, app. nos. 24816/14 and 25140/14, 10 March 2020, $\$ 116$.

13 See CAHILL, Amanda 'The human right to water - a right of unique status': The legal status and normative content of the right to water. The International Journal of Human Rights. 2005, vol. 9, no. 3, p. 391. 
Anand hypothesized that the incentive may have resulted from "increasing trend towards privatisation of water institutions and water resources", as well as aim to promote importance of access to water as enshrined in Millenium Development Goals. ${ }^{14}$ Another explanation of UN approach towards right to water, in particular upon scrutiny of the 2010 UN Human Rights Council (hereinafter "UN HRC") resolution 15/9, rests within the institutional position of the UN itself. It is argued that by recognizing right to water explicitly, the UN in fact sought to prevent itself from contesting its existence in the future, using the argument of estoppel. ${ }^{15}$

Yet all the caveats in approach or motiavation cannot deny the impact General Comment No. 15 had on development of the right to water and its so-called normative content. It does not merely provide a new conteptualization of right to water in the framework of international human rights law. It also serves as an authoritative source stating precise qualities of access to water that need to be observed, as well as safeguards that protect it. These include availability, accessibility, ${ }^{16}$ quality, as well as protection from discrimination of vulnerable groups or minorities. ${ }^{17}$ Additionally, the General Comment No. 15 recognizes the tripartite obligations to respect, protect, and fulfil right to water. ${ }^{18}$ In a manner consistent with other authorities, it treats right to water as encompassing the entirety of such obligations, embracing the applicability of the entire trio on right to water as part of economic, social and cultural rights, from cases of civil and political rights. ${ }^{19}$

The tripartite nature of obligations formerly originated in the work of Special Rapporteur on the Right to Food, ${ }^{20}$ although formerly the concept originated outside the UN system, which merely recognized it, while proposing four-partite system of obligations earlier. ${ }^{21}$ Yet throughout its development, essential contri-

14 ANAND, Prathivadi. Right to water and access to water: an assessment. Journal of International Development. 2007, vol. 19, no. 4, p. 516.

15 THIELBÖRGER, Pierre. The Right(s) to Water. Berlin, Heidelberg: Springer Berlin Heidelberg, 2014, p. 60.

16 In its various aspects, including not only physical accessibility, but also economic accessibility of affordable water for all, and information accesibility.

17 UN CESCR, General Comment No. 15 (2002) The right to water (arts. 11 and 12 of the International Covenant on Economic, Social and Cultural Rights), E/C.12/2002/11 (2002), paras. $12-16$.

18 UN CESCR, General Comment No. 15 (2002) The right to water (arts. 11 and 12 of the International Covenant on Economic, Social and Cultural Rights), E/C.12/2002/11 (2002), para. 20 et seq.

19 Cf. KOCH, Ida Elisabeth. The Justiciability of Indivisible Rights. Nordic Journal of International Law. 2003, vol. 72, no. 1, p. 9 for further discussion of the dichotomy

20 UN Commission on Human Rights, Report on the right to adequate food as a human right submitted by Mr. Asbjörn Eide, Special Rapporteur, E/CN.4/Sub.2/1987/23 (1987), paras. $112-114$.

21 THIELBÖRGER, Pierre. The "Essence" of International Human Rights. German Law Journal. 2019, vol. 20, no. 6, p. 927. 
butions were brought into the system, and in terms of General Comment No. 15 , elaboration on right to water by the UN CESCR brough input especially as regards obligation to fulfil, which it established with an extensive description regarded as "most comprehensive [...] available to date". ${ }^{22}$ Even more generally, the General Comment No. 15 is regarded as "by far the most relevant of all judicial or quasi-judicial recognitions of the right to water, and the one which elaborates the most on the normative content of such a right". ${ }^{23}$ The importance of this contribution rests in further disaggregation of fulfilment of human rights as comprising three separate sub-obligations states are required to do when fulfilling right to water: obligation to facilitate, obligation to promote, and obligation to provide. These cumulatively cover broad range of positive obligations states have, including assistance to individuals in order to help them enjoy their rights, education individuals on means how to properly enjoy their rights, and the focal point of this paper - provision of water to fulfil right to water of those individuals that cannot realize it themselves. ${ }^{24}$

The normative content of right to water and its elaboration, encompassed predominantly in General Comment No. 15, may prove to be even more consequential than its actual recognition, which is still subject to different narratives outlined above. In fact, the conducted empirical analysis (in several countries that incorporated right to water into their national legal orders) shows that formal recognition of right to water on national level per se does not lead to improved access to water without further consideration. In fact, the research shows that even absent such recognition, proper accountability mechanisms seem to be more essential in implementation of right to water than its explicit recognition. ${ }^{25}$ The opposing view nevertheless reiterates that in order to properly develop obligations under right to water and give them precise meaning, the human right to water must be recognized firstly, and clarified under international law. ${ }^{26}$ General Comment No. 15 therefore provides an essential input in both of these aspects, and its impact cannot be dismissed.

\section{Human right to water and its fulfilment in Slovakia}

Similarly to international human rights treaties, human right to water guaranteed for individuals is not recognized in the wording of human rights instru-

22 DE SCHUTTER, Olivier. International Human Rights Law. Cambridge: Cambridge University Press, 2019, p. 560.

23 THIELBÖRGER, Pierre. The Right(s) to Water. Berlin, Heidelberg: Springer Berlin Heidelberg, 2014, p. 64.

24 UN CESCR, General Comment No. 15 (2002) The right to water (arts. 11 and 12 of the International Covenant on Economic, Social and Cultural Rights), E/C.12/2002/11 (2002), para. 25.

25 ANAND, Prathivadi. Right to water and access to water: an assessment. Journal of International Development. 2007, vol. 19, no. 4, p. 524.

26 DE CHAZOURNES, Laurence Boisson. Fresh Water in International Law. Oxford: Oxford University Press, 2013, p. 155. 
ments in Europe. Nevertheless, several contentious areas have been identified, such as economic availability of drinking water in European states, as well as "future-proofing" water policies of European states and the EU Member States against possible adverse impact on currently satisfactory water standards, which are bound to arise due to climate change. ${ }^{27}$ The EU institutions remain actively seized of the matter, and even legislation formerly not dealing with right to water as an individual human right is being reconsidered, ${ }^{28}$ with the growing strength of voices calling for recognition of human-rights oriented approach throughout the EU by force of binding secondary law, and recognizing obligation to secure universal access to water ${ }^{29}$ Conversely, the $\mathrm{EU}$ is nevertheless also criticized for failure to develop policies dealing with human rights outside of its "internal experience" thus far. ${ }^{30}$ Since the topic has also been subject of European Citizens' Initiative Right2Water, it is nevertheless evident that the issue of right to water gains attention even in the $\mathrm{EU}$, and even the $\mathrm{EU}$ institutions approached the results of the ECI appreciably, at least when compared to other ECIs, ${ }^{31}$ and calls for action with involvement of the EU are well founded.

Concerning specifically Slovakia, but also situation of other European states, several authorities however also voiced their concerns as regards one particular category of obligations, that of non-discrimination, which has been more recently (and with increasing frequency) accentuated as one of obligations falling under the minimum core of human rights, one that is not subject to progressive realization..$^{32}$ Indeed, the obligation of securing "right of access to water and water facilities and services on a non-discriminatory basis, especially for disadvantaged or marginalized groups ${ }^{\prime \prime 3}$ has been recognized as forming material core of right to water even in General Comment No. 15, as an obligation of

27 THIELBÖRGER, Pierre. The Right(s) to Water. Berlin, Heidelberg: Springer Berlin Heidelberg, 2014, p. 38.

28 See preparations of recast Drinking Water Directive: European Commission, Proposal for a Directive of the European Parliament and of the Council on the quality of water intended for human consumption (recast), $\operatorname{COM}(2017) 753$ final (2018).

29 Cf. European Parliament, Resolution on the follow-up to the European Citizens' Initiative Right2Water, 2014/2239(INI) (8 September 2015); or European Economic and Social Committee, Opinion of the European Economic and Social Committee on the Communication from the Commission on the European Citizens' Initiative Water and sanitation are a human right! Water is a public good, not a commodity! (COM(2014) 177 final) (own-initiative opinion) 2015 OJ C 12 (15 October 2014).

30 MOKRÁ, Lucia, JANKOVÁ, Kristína. EU as a human rights actor? Bratislava Law Review. 2018, vol. 2, no. 2, p. 103.

31 KARATZIA, Anastasia. The European Citizens' Initiative and the EU Institutional Balance: On Realism and the Possibilities of Affecting EU Lawmaking. Common Market Law Review. 2017, vol. 54, no. 1, pp. 186-190.

32 Cf. YOUNG, Katharine G. The Minimum Core of Economic and Social Rights: A Concept in Search of Content. Yale Journal of International Law. 2008, vol. 33, no. 1, p. 156.

33 UN CESCR, General Comment No. 15 (2002) The right to water (arts. 11 and 12 of the International Covenant on Economic, Social and Cultural Rights), E/C.12/2002/11 (2002), para. $37(b)$. 
immediate effect. Its aim is to provide special consideration for cases of groups which have been subjected to systematic discrimination, and are therefore particuralry vulnerable to discrimination, either in law or in fact. ${ }^{34}$ Drawing from the elaboration on the definition of particularly vulnerable groups provided by the ECtHR, certain identified groups are considered particularly vulnerable across all of Europe, in separate cases considered by the ECtHR against a great variety of respondent states, ${ }^{35}$ including a number of post-communist countries in Central Europe. The ECtHR considered also several cases where the widespread discrimination and particular vulnerability of Roma was considered a factor in Slovakia specifically, whether in cases of right to life, ${ }^{36}$ prohibition of ill-treatment, ${ }^{37}$ or protection of bodily integrity. ${ }^{38}$

Thus, it should come as no surprise that the emphasis on vulnerable groups and non-discrimination in the context of right to water shed light and led to scrutiny of situation of Roma and their access to water. The issue has been highlighted in concluding observations of the UN CESCR addressed to a variety of EU Member States states, with increasing occurrence in recent years, and the UN Committee on the Elimination of Racial Discrimination (hereinafter "UN CERD") also voiced its concerns. ${ }^{39}$ Only two Member States have been condemned for insufficient living conditions of Roma and their access to water by both the UN CESCR and UN CERD simultaneously, the pair being Greece and Slovakia. ${ }^{40}$

34 TEIXEIRA, Camila. Priority, agency and cooperation: how international human rights law helps fulfil the economic and social rights of the most vulnerable. The International Journal of Human Rights. 2020, vol. 24, no. 8, pp. 1034-1035.

35 See PERONI, Lourdes, TIMMER, Alexandra. Vulnerable groups: The promise of an emerging concept in European Human Rights Convention law. International Journal of Constitutional Law. 2013, vol. 11, no. 4, pp. 1063-1070.

36 ECtHR, Mižigárová v. Slovakia, app. no 74832/01, 14 December 2010.

37 ECtHR, Koky and others v. Slovakia, app. no. 13624/03, 12 June 2012, para. 239.

38 ECtHR, V.C. v. Slovakia, app. no. 18968/07, 8 November 2011, $\$ 154 ;$ I.G. and others v. Slovakia, app. no. 15966/04, 13 November 2012, paras. 143-145.

39 See e. g. Concluding observations on the fifth periodic report of Italy, E/C.12/ITA/CO/5, 28 October 2015, paras. 44-45; Concluding observations on the sixth periodic report of the United Kingdom of Great Britain and Northern Ireland, E/C.12/GBR/CO/6, 14 July 2016, paras. 49-50; Concluding observations on the sixth periodic report of Bulgaria, E/C.12/BGR/CO/6, 29 March 2019, paras. 35-36; UN CERD, Concluding observations on the combined second to fifth periodic reports of Serbia, CERD/C/SRB/CO/2-5, 3 January 2018, paras. 22-23.

40 See also UN CESCR, Concluding observations on the third periodic report of Slovakia, E/C.12/SVK/CO/3, 14 November 2019, paras. 33-36; Concluding observations on the second periodic report of Greece, E/C.12/GRC/CO/2, 27 October 2015, paras. 33-34 and UN CERD, Concluding observations on the combined eleventh and twelfth periodic reports of Slovakia, CERD/C/SVK/CO/11-12, 12 January 2018, paras. 21-22; Concluding observations on the twentieth to twenty-second periodic reports of Greece, CERD/C/GRC/CO/20-22, 3 October 2016, paras. 20-21. 
The issues of access to water for Roma communities in Slovakia have been also emphasized by various NGOs, ${ }^{41}$ e. g. when they provided UN human rights bodies with insight into problematic areas of implementing the ICESCR provisions in Slovakia, with statistical data, analysis, or case-studies for the panels to consider. ${ }^{42}$ It has been found that Slovakia is in violation of its positive obligations related to non-discrimination on the basis of race, and that such violations are of a systematic nature. ${ }^{43}$ The hardships are manifested even in cases of inequal access to water, and despite the ongoing criticism, were also exacerbated by the ongoing pandemic of the SARS-CoV-2 virus, implications of which were once again pointed out. ${ }^{44}$

Apart from criticism of human rights bodies, the research and studies conducted so far similarly established presence of disproportionate impact of

41 e. g. European Roma Rights Centre. Thirsting for Justice. Europe's Roma Denied Access to Clean Water and Sanitation. Budapest: European Roma Right Centre, 2017.

42 Reports before the UN CESCR and UN CERD, as well as United Nations Committee on the Rights of the Child (hereinafter „UN CRC) that specifically include topics of access to water for marginalized or segregated communities of Roma were provided by various NGOs, often collaborating on the so-called „shadow reports“: European Roma Rights Centre and Center for Civil and Human Rights (Poradňa pre občianske a ludské práva), Written Comments of the European Roma Rights Centre and Center for Civil and Human Rights, Concerning Slovakia. [online]. Available at: <https://tbinternet.ohchr.org/Treaties/CRC/ Shared\%20Documents/SVK/INT_CRC_NGO_SVK_23781_E.pdf> accessed 5.9.2020; European Roma Rights Centre and Forum for Human Rights, Written Comments of the European Roma Rights Centre and the Forum for Human Rights Concerning Slovakia For the Consideration of the United Nations Committee on the Elimination of Racial Discrimination to the 94th Session (20 November - 8 December 2017), [online]. Available at: <https:// tbinternet.ohchr.org/Treaties/CERD/Shared\%20Documents/SVK/INT_CERD_NGO_ SVK_29438_E.pdf > accessed 5.9.2020 >; European Roma Rights Centre, Written comments by the European Roma Rights Centre for the consideration of the Committee on Economic, Social and Cultural Rights at its 62nd session, 3 April 2018 - 6 April 2018, [online]. Available at: <https://tbinternet.ohchr.org/_layouts/15/treatybodyexternal/Download.aspx? symbolno=INT\%2fCESCR\%2fICO\%2fSVK\%2f29942\&Lang=en> accessed 5.9.2020>; Forum for Human Rights and Center for Civil and Human Rights (Poradňa pre občianske a ludské práva), NGOs information to the UN Committee on Economic, Social and Cultural Rights For Consideration when Compiling the Concluding Observations on the Third Periodic Report of the Slovak Republic under the International Covenant on Economic, Social and Cultural Rights, [online] Availble at: <https://tbinternet.ohchr.org/Treaties/CESCR/ Shared\%20Documents/SVK/INT_CESCR_CSS_SVK_35669_E.pdf> accessed 5.9.2020.

43 MOKRÁ, Lucia. The Slovak Republic's Positive Obligation Regarding Human Rights and Against Racial Discrimination. Legal Science: Functions, Significance and Future in Legal Systems II, 2020.

44 THOOMPAIL, Meera. Targeted COVID-19 testing in Roma settlements in Slovakia - A positive measure or further stigmatization?, [online]. Available at: $<\mathrm{ttps}: / /$ minorityrights. org/2020/06/02/roma-slovakia-covid-testing/> accessed 11.11.2020; BIKÁR, František. Slovakia's Romani settlements are very endangered by the COVID-19 pandemic, some have no access to potable water [online]. Available at: <http://www.romea.cz/en/news/world/ slovakia-apos-s-romani-settlements-are-very-endangered-by-the-covid-19-pandemicsome-have-no-access-to-potable-water> accessed 12.11.2020 
infringements of access to water and associated rights on Roma communities. As soon as 2006, years before Slovakia was criticized for environmental inequalities related to drinking water by the UN CESCR for the first time, ${ }^{45}$ a study of the United Nations Development Programme (hereinafter "UNDP”) already found that only $54,8 \%$ Roma households gain access to water through public water supply, compared to $85,9 \%$ of other households. ${ }^{46}$ Additionally, 45,2\% of Roma households had their primary water source located away from their own household. ${ }^{47}$ Further study confirmed the persisting presence of inequal conditions of access to water among vulnerable Roma communities and other households, even pointing out the deteriorating trend, with $41,6 \%$ of Roma households being located further than 50 metres from their primary water source, ${ }^{48}$ a substantial increase from $16,9 \%$ reported in the earlier study. ${ }^{49}$ Similarly, the proportion of Roma communities using non-standard water sources, such as springs or streams in their vicinity, increased from $3,9 \%$ to $5,7 \% .{ }^{50}$

Accesibility is however not the only component of right to water, as recognized in the General Comment No. 15, which is found to be lacking in Roma households. Other authorities point out also lack of economic affordability of provided water for Roma communities which often combat poverty and residential segregation. ${ }^{51}$ Further obstacles for affordability of drinking water were found even in municipalities where infrastructure and public water pipelines were constructed, but the users were charged excessive lump sum payments not based on their actual water consumption, and faced terminations of water supply, lasting years in some cases. ${ }^{52}$

45 For the first assessment of Slovakia and its fulfilment of the right to water as regards marginalized groups before the UN CESCR, see Concluding observations of the Committee on Economic, Social and Cultural Rights. Slovakia, E/C.12/SVK/CO/2, 8 June 2012, paras. 21.

46 FILADELFIOVÁ, Jarmila, GERBERY, Daniel, ŠKOBLA, Daniel. Správa o životných podmienkach rómskych domácností na Slovensku. Bratislava: United Nations Development Programme, 2006, p. 44.

47 FILADELFIOVÁ, Jarmila, GERBERY, Daniel, ŠKOBLA, Daniel. Správa o životných podmienkach rómskych domácností na Slovensku. Bratislava: United Nations Development Programme, 2006, p. 44.

48 FILADELFIOVÁ, Jarmila, GERBERY, Daniel. Správa o životných podmienkach rómskych domácností na Slovensku 2010. Bratislava: United Nations Development Programme, 2012, p. 68.

49 FILADELFIOVÁ, Jarmila, GERBERY, Daniel, ŠKOBLA, Daniel. Správa o životných podmienkach rómskych domácností na Slovensku. Bratislava: United Nations Development Programme, 2006, p. 44.

50 FILADELFIOVÁ, Jarmila, GERBERY, Daniel, ŠKOBLA, Daniel. Správa o životných podmienkach rómskych domácností na Slovensku. Bratislava: United Nations Development Programme, 2006, p. 44; FILADELFIOVÁ, Jarmila, GERBERY, Daniel. Správa o životných podmienkach rómskych domácností na Slovensku 2010. Bratislava: United Nations Development Programme, 2012, p. 67.

51 FILČÁK, Richard, STEGER, Tamara. Ghettos in Slovakia. Confronting Roma Social and Enviromental Exclusion. Analyse \& Kritik. 2014, vol. 36, no. 2, p. 242.

52 FILČÁK, Richard, SZILVASI, Marek, ŠKOBLA, Daniel. No water for the poor: the Roma 
Further issues regarding availability, accessibility, quality, and equality in securing right to water were observed, including Roma people having to walk up to 25 minutes to reach water sources, which were often used by wild or stray animals, or were not at all checked for safety for human consumption or pollution. In some cases, the only available water source was either guarded or out of service, apart from designated hours, during which residents often found it unable to secure sufficient amount of water for everyone. These communities also face significant challenges related also to water quality, as many times the water sources were not only untested, but also established in vicinity of environmentally hazardous conditions, and substantial amounts of diseases and medical conditions were reported in several of such areas..$^{53}$

Importantly, the deficiencies in safeguarding right to water for vulnerable communities are no longer matters of criticism aimed towards Slovakia externally by the international community. The issue has been highlighted also by the Ombudsperson of Slovakia in her report, which recalled many of the situations outlined above and corroborated them with own case-studies. The Ombudsperson also provided insight into the perceived reasons why right to water remains unfulfilled amongst Roma communities, citing lack of state financing, cooperation with self-governing municipalities, and unresolved land disputes and permission proceedings regarding construction of new infrastructure for public water supply. ${ }^{54}$ The report is also the first among those authored by state authorities, which recognizes that the situation in Slovakia as regards water security fails to secure even the minimum core obligations. ${ }^{55}$ Certainly, in light of the abovementioned findings, it can be concluded that not only water security remains a critical failure of minimum core obligations incumbent upon Slovakia, but similar implications arise in terms of physically accessible water, as well as economically accessible (affordable) water, secured through infrastructure located within reasonable distance from households of marginalized Roma communities. ${ }^{56}$

ethnic minority and local governance in Slovakia. Ethnic and Racial Studies. 2018, vol. 41, no. 7, pp. 1397-1399.

53 FILČÁK, Richard, SZILVASI, Marek, ŠKOBLA, Daniel. No water for the poor: the Roma ethnic minority and local governance in Slovakia. Ethnic and Racial Studies. 2018, vol. 41, no. 7.

54 Ombudsperson of Slovakia. Správa o prieskume dodržiavania základných ludských práv a slobôd. Prístup k pitnej vode a informácia o zabezpečení protipožiarnej ochrany v rómskych osadách (Report on Survey of Compliance with Fundamental Human Rights and Freedoms. Access to Drinking Water. [online]. Available at: < https://www.vop.gov.sk/files/ Pristup_k_vode.pdf > p. 19, accessed 14.10.2020.

55 Ombudsperson of Slovakia. Správa o prieskume dodržiavania základných ludských práv a slobôd. Prístup k pitnej vode a informácia o zabezpečení protipožiarnej ochrany v rómskych osadách (Report on Survey of Compliance with Fundamental Human Rights and Freedoms. Access to Drinking Water. [online]. Available at: < https://www.vop.gov.sk/files/ Pristup_k_vode.pdf> p. 26, accessed 14.10.2020.

56 Cf. UN CESCR, General Comment No. 15 (2002) The right to water (arts. 11 and 12 of the International Covenant on Economic, Social and Cultural Rights), E/C.12/2002/11 (2002), para. $37(\mathrm{c})$. 


\section{Securing compliance: incentives for regional administration and mea- ningful impact of public procurement?}

The calls for action and criticism aimed at Slovakia has been met with various responses on part of state. Firstly, in order to properly monitor the situation, Slovak authorities collaborated closely with many stakeholders, predominantly academia and the UNDP, in order to produce basic reference framework for public bodies, as well as private undertakings and NGOs to provide essential data about Roma communities and their living conditions, infrastructure, education, as well as demographics. This culminated in creation of the Atlas of Roma Communities in Slovakia 2013 (hereinafter "2013 Atlas"), which collected also broad spectrum of data on various aspects related to access to water, disaggregated on regional basis and the level of segregation persisting in the communities. The findings corroborate those made previously and later on as well, describing disproportionate lack of access to water in Roma communities, especially those experiencing residential segregation..$^{57}$ The notable feature of the research is its scale, gathering data in 801 localities in all regions of Slovakia. More importantly, the Atlas of Roma Communities is currently being prepared in its third iteration, using data from 2019 (hereinafter "2019 Atlas")..$^{58}$ The new iteration, as well as future regular updates to the datasets will allow researchers, as well as human rights institutions, independent monitors, and international bodies, to properly establish the progress in developing infrastructure required to secure access to water, and fulfil right thereto. Through these regular assessments, changes in composition of population with sufficiently secured access to water may be assessed, with Slovakia thereby satisfying another of core obligations required by the UN CESCR, that of monitoring realization of right to water on its territory. ${ }^{59}$

Additionally, it seems the Atlas was also regarded as a benchmark of sorts when Slovakia at least tacitly recognized its value in determining locations where further investments aimed to secure access water are needed. Thus, the municipalities in Slovakia can currently apply for funding from the European Regional Development Fund (hereinafter "ERDF") to secure financing of projects secur-

57 MUŠINKA, Alexander, ŠKOBLA, Daniel, HURRLE, Jakub, MATOVIČOVÁ, Kvetoslava, KLING, Jaroslav. Atlas of Roma Communities in Slovakia 2013. Bratislava: United Nations Development Programme, 2014.

58 The raw data from the new iteration were formerly available online, URL: https://www. minv.sk/?atlas-romskych-komunit-2019, accessed 20.10.2020. However, at the time of writing this article, the data are no longer available, and Ministry of the Interior of Slovakia published only a short note explaining that the data are being verified. The only information available at the website is a list of municipalities where the data were collected, totalling now 825 municipalities, a slight increase from 801 in 2013.

59 UN CESCR, General Comment No. 15 (2002) The right to water (arts. 11 and 12 of the International Covenant on Economic, Social and Cultural Rights), E/C.12/2002/11 (2002), para. $37(\mathrm{~g})$. 
ing drinking water for Roma communities, only if the municipality is listed in the 2019 Atlas. $^{60}$ It has to be noted that such condition was not stated in the earlier call for aplications from December 2016, where all municipalities with marginalized Roma communities were eligible to apply, totalling 1043 municipalities, ${ }^{61}$ a substantially higher amount than municipalities eligible under the new 2019 Atlas. The change in approach of Slovakia therefore currently means that among municipalities where Roma inhabitants reside, not only part of them are not statistically analysed and their data remain uncollected in the 2019 Atlas, but the very same municipalities are excluded from possibility to secure funding from the ERDF to improve their situation.

The question that has to be addressed afterwards is the efficiency of such projects, and the benefits they bring for the communities concerned. Generally, a variety of such fundings have been considered by Škobla and Filčák, and concerning Roma communities, they established three most common cases - when a project is aimed towards improving the living conditions of Roma, it either misses real impact on them, improves living conditions but fosters segregation at the same time, or improves them only on the basis of pre-existing favourable conditions. ${ }^{62}$ However, in the case of securing acces to water in Roma communities, it seems the funds that were to be provided by the ERDF are in fact left without any motivation on part of the municipalities whatsoever. In the 2016 call for applications (already concluded), only 53 municipalities out of all 1043 eligible applied for funding, and only 35 applications were in fact granted. Out of 16054814 EUR allocated by the ERDF for the applications, only 2310969,63 EUR were in fact awarded in the 6 rounds of applications between March 2017 and November 2018, representing less than $6,95 \%$ of the funds available. ${ }^{63}$

The 2016 ERDF project is significant for yet another reason, as it provides opportunities to assess the approach of municipalities, especially smaller ones, towards incorporating social aspects into public procurement. It has to be noted at the outset that out of the 35 awarded funds, only 5 were exceeding sum

60 Details of the 2020 Ministry of Interior call for applications are available online, URL: https://www.minv.sk/?aktualne-vyzvy-na-predkladanie-ziadosti-o-nenavratny-financny-prispevok\&sprava=vyzva-zamerana-na-podporu-pristupu-k-pitnej-vode-v-prostredi-m$\mathrm{rk}$, accessed 30.10.2020.

61 Details of the 2016 Ministry of Interior call for applications are available online, URL: http://www.minv.sk/?archiv-vyziev-3\&sprava=vyzva-zamerana-na-podporu-pristupu-k-pitnej-vode-oplz-po6-sc611-2016-3-uzavreta-dna-16-novembra-2018, accessed 30.10.2020.

62 ŠKOBLA, Daniel, FILČÁK, Richard. Infrastructure in Marginalised Roma Settlements: Towards a Typology of Unequal Outcomes of EU Funded Projects. Sociológia. 2016, vol. 48 , no. 6 .

63 Apart from details provided in the 2016 Ministry of Interior call for applications, see also UN CESCR, List of issues in relation to the third periodic report of Slovakia. Addendum. Replies of Slovakia to the list of issues, E/C.12/SVK/Q/3/Add.1, 11 July 2019, p. 13 for more details. 
of 180000 EUR, the threshold above which contracting authorities may be required by law to consider social aspects either as contract award criterion, or condition for performance of contract. ${ }^{64}$ Moreover, the obligation to include social aspects under Slovak law triggers only in case the contracting authority has initiated at least ten public procurement contracts exceeding such threshold within the previous year. Therefore, apart from several rare cases, the social aspects in public procurement are unlikely to be required by legislation in cases of current projects addressing water scarcity in Slovakia. Indeed, it seems to follow the broader approach across the EU, where public contracts are not open to borderless mandatory inclusion of social aspects or protection of human rights, but remain merely factors to be considered and counterbalanced with the more general principles of public procurement, such as transparency. ${ }^{65}$

In contrast, the criteria for applications in 2016 stipulated that once municipality secures ERDF funding, it is required to oblige the contractor in the awarded contract to employ at least one unemployed person from marginalized Roma communities, with accent especially on long-term unemployment. ${ }^{66}$ The project therefore takes an expansionist position towards social aspets, seeking to push municipalities towards their implementation in public procurement even when they are not required to do so by legislation. These attempts correspond to broader aim of securing protection of human rights and social considerations among economic operators in the area of public contracts. ${ }^{67}$ However, proper consideration of the actual projects undertaken shows the reality where formally, the social aspects are firmly entrenched in practice, but their actual impact on specific communities appears detached from their needs and incapable of addressing the root causes of discrimination.

Out of all 35 municipalities that secured funding in the 2016 ERDF project, the available data show that in at least 14 cases, it cannot be conclusively ascertained whether in fact social aspects of public procurement were deployed. In certain cases, the projects awarded funding were not yet performed, in other cases, no documents allowing for such assessment were available, or the results

64 Directive 2014/24/EU of the European Parliament and of the Council of 26 February 2014 on public procurement and repealing Directive 2004/18/EC, OJ L 94/65, 28 March 2014, arts. 67 and 70; cf. Slovak Act no. 343/2015 Coll. on public procurement, 18 November $2015, \S \$ 5,10(7)$, and 44 .

65 BLAŽO, Ondrej, PATAKYOVÁ, Mária T. International Responsibility of Business for Violation of Human Rights - Customers' Perspective. Białostockie Studia Prawnicze. 2019, vol. 24 , no. 2.

66 Annex no. 9 to the 2016 Ministry of Interior call for applications, [online]. Available at: <http://www.minv.sk/swift_data/source/mvsr_a_eu/oplz/vyzvy/Vyzva\%20-\%20Voda\%20 2016/Priloha\%20c.\%209\%20-\%20Podmienky\%20poskytnutia\%20prispevku\%20a\%20 sposoby\%20ich\%20overovania.pdf>, p. 13, accessed 20.10.200.

67 Cf. BLAŽO, Ondrej, KOVÁČIKOVÂ, Hana. Right for Equal Opportunity for Fair Public Contract? Human Rights in Public Procurement. Białostockie Studia Prawnicze. 2019, vol. 24, no. 2 . 
were inconclusive as to the actual question whether contractors were in the end required to act upon the social asepcts required by the conditions of the ERDF call for applications. In at least two cases, ${ }^{68}$ the contractual provision had been entirely omitted from the final contract which municipality concluded. These cases are symptomatic of more significant, systematic problem that plagued many of the municipalities.

As described above, only very rarely did the projects exceed the threshold of $180000 \mathrm{EUR}$, and on the other hand, projects with lower costs frequently aimed to secure access to drinking water via buying and installing water dispensing machines in public places, where Roma communities can obtain drinking water via keycards or similar means. Such method required generally much less funds than municipalities which sought to expand their existing water supply pipelines. ${ }^{69}$ This presents an appeal in providing an easy and cost-efficient way of securing essential access to water as quickly as possible. On the other hand, the procurement and construction of such temporary infrastructure is much less laborious. In some cases, like Prakovce or Moldava nad Bodvou, the simplicity of this solution may be the reason why the concluded contracts in fact did not incorporate the said social aspects, effectively negating any attempts of the funding scheme to promote them. However, even in cases where contracts related to sale or construction of similar water-dispensing machines incorporated such obligations, it is unlikely such lesser contracts with insignificant amount of work required are capable of securing the desired outcomes and promote employment in the long-term. Requirement of securing employment for Roma is, in cases of low-cost contracts that do not require extensive construction work or manpower, is therefore rendered an impertinent condition that is not sufficient to provide long-term benefits in the vulnerable communities, however good its intentions may be. On the contrary, question arises whether social aspects in the described situation are regarded more as a formality to be disposed of without much ado. Such lax approach may be evidenced by the conduct of several municipalities, where the social aspects were e. g. implemented into the contract only belatedly, as an annex to the original wording, or the obligation to employ Roma was included without any real provision dealing with liability or remedy for failure to follow the conditions in performance of the contract. ${ }^{70}$

68 The municipality of Prakovce, contract for sale of June 2019, [online]. Available at: <https://www.prakovce.sk/download_file_f.php?id=1162307, accessed 1.11.2020; and the municipality of Moldava nad Bodvou, contract for work of April 2018, [online]. Available at: <https://egov.moldava.sk/FileOutputHttpHandler.ashx?arguments=CKgi\%2bQV\%2b2WhY5kRLFEUAXWe\%2fTqmrN0E9QQ7fqsiZFxsfl6tGpR39PkirSFn82PljWxbOcSTzqF8ahopVM0HwdvwY1F8UyuUudw\%3d\%3d>, accessed 1.11.2020.

69 Case in point where the cost of work exceeded $464000 €$ is the municipality of Červenica, contract for work of October 2018, [online]. Available at: <https://www.uvo.gov.sk/vyhladavanie-dokumentov/detail/3039797> accessed 1.11.2020.

70 E. g. the municipality of Spišský Štvrtok, annex no. 1 to the contract for work of December 2017, [online]. Available at: <https://www.uvo.gov.sk/vyhladavanie-dokumentov/ 
Additionally, these deficiencies can be found even in municipalities where the more expansive approach to drinking water provision is taken, and authorities in fact contract to construct entire water supply infrastructure for Roma communities. Even in cases of large and lengthy projects, lack of real effort to ensure social aspects in public procurement bring a meaningful impact on the communities concerned can therefore be inferred, similarly to projects opting for temporary and insufficient solutions.

Compared with the newer ERDF call for applications from 2020, the employment of vulnerable individuals from Roma communities (especially facing longterm unemployment) is no longer is a condition for performance of a contract, and remains only one of the monitored deliverables. ${ }^{71}$ Municipalities that secure the ERDF funding are no longer required to seek securing of employment among marginalized communities, merely to monitor whether such social aspects were implemented. It would seem that the overall ambition to use public procurement to promote social approach towards Roma communities facing water shortage are accordingly a failed and abandoned attempt. On the other hand, the change of paradigm may acknowledge also the root cause of the problem resting within the entire scheme. Provision of accessible, affordable and safe drinking water in line with international obligations of Slovakia having immediate effect is one of many goals to be undertaken to secure change in structural inequalities. High unemployment rate and need of improved integration of Roma into the labour market is yet another matter, one that faces criticism for its implementation in itself. $^{72}$ Perhaps it is therefore premature to attempt interlinking two disparate issues plagueing the same group, as the attempt to do so analysed in this paper yielded results that do not seem to be mutually beneficial towards the solution of either underlying problem.

\section{Conclusion}

This paper sought to assess the impact of public procurement and social aspects therein on enjoyment of right to water amongst vulnerable Roma communities in Slovakia. The situation of these groups in the country is well-documented and frequently criticized from various points of view, many of them grounded in the fact that water rights in Slovakia are not adhering to various

detail/914373>, accessed 5.11.2020; the municipality of Rankovce, contract for work of May 2019, [online]. Available at: <https://www.obecrankovce.sk/download_file_f. php?id=1155880 $>$ accessed 5.11.2020.

71 Ministry of Interior of the Slovak Republic, Výzva zameraná na podporu prístupu k pitnej vode v prostredí MRK, [online]. Available at: <http://www.minv.sk/?aktualne-vyzvy-na-predkladanie-ziadosti-o-nenavratny-financny-prispevok\&sprava=vyzva-zamerana-na-podporu-pristupu-k-pitnej-vode-v-prostredi-mrk> accessed 28.10.2020>.

72 GRILL, Jan. Re-learning to labour? 'Activation Works' and new politics of social assistance in the case of Slovak Roma. Journal of the Royal Anthropological Institute. 2018, vol. 24, no. S1. 
aspects of normative content of right to water, as recognized and developed in international practice.

It has been reported that countries frequently lack objective methods to assess the social aspects in public procurement procedures. ${ }^{73}$ Slovakia has created widespread and complex database of information about living conditions and situation of Roma living in its terriritory, through multiple iterations of its Atlas of Roma Communities. These data also provided foundations for determining the regions where public funding would be directed towards improving provision of water to at the very least secure compliance with international standards. Yet as this paper explained, the utilization of such funding came with several notable setbacks. Firstly, the available funding has gone by mostly unnoticed by the responsible authorities so far, and over since 2016, a minority of the overall amount available had been actually granted to the applicants. Secondly, even where funding has been in fact secured, it has often resulted in small-scale projects that provided water through publicly accessible machines, without adhering to the principle of accessibility and affordability of water for each individual household. Thirdly, with the primary goal of securing water for deproved communities of Roma already remaining largely unfulfilled, the interplay of social aspects and employment opportunities for the same communities remains largely an unfulfilled promise. The incorporation of social aspects as mandatory resulted in a mix of non-compliance, unreliable data or hampered monitoring, and law, disinterested approach of authorities to genuinely become engaged in the process. In order to overcome these hardships, the policies are in need of a paradigm shift, either intertwining them together more effectively, supplemented with effective incentives, as well as monitoring and enforcement mechanisms, or, alternatively, separating the issue of unemployment and access to water into separate arenas and devoting individualized approach to both venues. Only then can the current situation progress towards genuine improvement of situations violationg human rights that currently expose Slovakia to condemnation of the international community.

\section{List of references}

ANAND, Prathivadi. Right to water and access to water: an assessment. Journal of International Development. 2007, vol. 19, no. 4, pp. 511-526.

BLAŽO, Ondrej, KOVÁČIKOVÁ, Hana. Right for Equal Opportunity for Fair Public Contract? Human Rights in Public Procurement. Białostockie Studia Prawnicze. 2019, vol. 24, no. 2, pp. 137-146.

BLAŽO, Ondrej, PATAKYOVÁ, Mária T. International Responsibility of Business for Violation of Human Rights - Customers' Perspective. Białostockie Studia Prawnicze. 2019, vol. 24, no. 2, pp. 101-122.

73 MONTALBÁN-DOMINGO, Laura, GARCÍA-SEGURA, Tatiana, SANZ, Amalia, PELLICER, Eugenio. Social sustainability criteria in public-work procurement: An international perspective. Journal of Cleaner Production 2018, vol. 198, p. 1368. 
BRAIG, Katharina Franziska. The European Court of Human Rights and the right to clean water and sanitation. Water Policy, 2018, vol. 20, no. 2, pp. 282-307.

CAHILL, Amanda 'The human right to water - a right of unique status': The legal status and normative content of the right to water. The International Journal of Human Rights. 2005, vol. 9, no. 3, pp. 389-410.

DE CHAZOURNES, Laurence Boisson. Fresh Water in International Law. Oxford: Oxford University Press, 2013.

European Roma Rights Centre. Thirsting for Justice. Europe's Roma Denied Access to Clean Water and Sanitation. Budapest: European Roma Right Centre, 2017.

FILADELFIOVÁ, Jarmila, GERBERY, Daniel. Správa o životných podmienkachrómskych domácnostína Slovensku 2010. Bratislava: United Nations Development Programme, 2012.

FILADELFIOVÁ, Jarmila, GERBERY, Daniel, ŠKOBLA, Daniel. Správa o životných podmienkach rómskych domácností na Slovensku. Bratislava: United Nations Development Programme, 2006.

FILČÁK, Richard, STEGER, Tamara. Ghettos in Slovakia. Confronting Roma Social and Enviromental Exclusion. Analyse \& Kritik. 2014, vol. 36, no. 2, pp. 229-250.

FILČÁK, Richard, SZILVASI, Marek, ŠKOBLA, Daniel. No water for the poor: the Roma ethnic minority and local governance in Slovakia. Ethnic and Racial Studies. 2018, vol. 41, no. 7, pp. 1390-1407.

GRILL, Jan. Re-learning to labour? 'Activation Works' and new politics of social assistance in the case of Slovak Roma. Journal of the Royal Anthropological Institute. 2018, vol. 24, no. S1, pp. 511-526.

KARATZIA, Anastasia. The European Citizens' Initiative and the EU Institutional Balance: On Realism and the Possibilities of Affecting EU Lawmaking. Common Market Law Review. 2017, vol. 54, no. 1, pp. 177-208.

$\mathrm{KOCH}$, Ida Elisabeth. The Justiciability of Indivisible Rights. Nordic Journal of International Law. 2003, vol. 72, no. 1, pp. 3-39.

MCCAFFREY, Stephen. A Human Right to Water: Domestic and International Implications. Georgetown International Environmental Law Review. 1992, vol. 5, no. 1.

MOKRÁ, Lucia, JANKOVÁ, Kristína. EU as a human rights actor? Bratislava Law Review. 2018, vol. 2, no. 2, pp. 91-105.

MONTALBÁN-DOMINGO, Laura, GARCÍA-SEGURA, Tatiana, SANZ, Amalia, PELLICER, Eugenio. Social sustainability criteria in public-work procurement: An international perspective. Journal of Cleaner Production 2018, vol. 198, pp. 1355-1371.

MUŠINKA, Alexander, ŠKOBLA, Daniel, HURRLE, Jakub, MATOVIČOVÁ, Kvetoslava, KLING, Jaroslav. Atlas of Roma Communities in Slovakia 2013. Bratislava: United Nations Development Programme, 2014.

PERONI, Lourdes, TIMMER, Alexandra. Vulnerable groups: The promise of an emerging concept in European Human Rights Convention law. International Journal of Constitutional Law. 2013, vol. 11, no. 4, pp. 1056-1085.

DE SCHUTTER, Olivier. International Human Rights Law. Cambridge: Cambridge University Press, 2019.

SCOTT, Craig. Interdependence and Permeability of Human Rights Norms: Towards a Partial Fusion of the International Covenants on Towards a Partial Fusion of the International Covenants on Human Rights Human Rights. Osgoode Hall Law Journal. 1989, vol. 27, no. 3, pp. 769-878.

ŠKOBLA, Daniel, FILČÁK, Richard. Infrastructure in Marginalised Roma Settlements: 
Towards a Typology of Unequal Outcomes of EU Funded Projects. Sociológia. 2016, vol. 48 , no. 6 , pp. 551-571.

TEIXEIRA, Camila. Priority, agency and cooperation: how international human rights law helps fulfil the economic and social rights of the most vulnerable. The International Journal of Human Rights. 2020, vol. 24, no. 8, pp. 1031-1056.

THIELBÖRGER, Pierre. The "Essence" of International Human Rights. German Law Journal. 2019, vol. 20, no. 6, pp. 924-939.

THIELBÖRGER, Pierre. The Right(s) to Water [online]. Berlin, Heidelberg: Springer Berlin Heidelberg, 2014.

WILDER, Margaret, INGRAM, Helen. Knowing Equity When We See It: Water Equity in Contemporary Global Contexts. In: CONCA, Ken, WEINTHAL, Erika (eds) The Oxford Handbook of Water Politics and Policy. New York: Oxford University Press, 2016.

YOUNG, Katharine G. The Minimum Core of Economic and Social Rights: A Concept in Search of Content. Yale Journal of International Law. 2008, vol. 33, no. 1, pp. 113-175.

ZELEŇÁKOVÁ, Martina, FENDEKOVÁ, Miriam. Key Facts About Water Resources in Slovakia. In: NEGM, Abdelazim M, ZELEŇÁKOVÁ, Martina. (eds). Water Resources in Slovakia: Part I. Cham: Springer International Publishing, 2018, pp. 3-19.

\section{Legislation}

Directive 2014/24/EU of the European Parliament and of the Council of 26 February 2014 on public procurement and repealing Directive 2004/18/EC, OJ L 94/65, 28 March 2014.

Slovak Act no. 343/2015 Coll. on public procurement, 18 November 2015.

Documents of international bodies

United Nations Commission on Human Rights, Report on the right to adequate food as a human right submitted by Mr. Asbjörn Eide, Special Rapporteur, E/CN.4/Sub.2/1987/23 (1987).

United Nations Committee on Economic, Social and Cultural Rights, General Comment No. 15 (2002) The right to water (arts. 11 and 12 of the International Covenant on Economic, Social and Cultural Rights), E/C.12/2002/11 (2002).

United Nations Committee on Economic, Social and Cultural Rights, Concluding observations of the Committee on Economic, Social and Cultural Rights. Slovakia, E/C.12/ SVK/CO/2, 8 June 2012.

United Nations Committee on Economic, Social and Cultural Rights, Concluding observations on the second periodic report of Greece, E/C.12/GRC/CO/2, 27 October 2015.

United Nations Committee on Economic, Social and Cultural Rights, Concluding observations on the fifth periodic report of Italy, E/C.12/ITA/CO/5, 28 October 2015.

United Nations Committee on Economic, Social and Cultural Rights, Concluding observations on the sixth periodic report of the United Kingdom of Great Britain and Northern Ireland, E/C.12/GBR/CO/6, 14 July 2016.

United Nations Committee on Economic, Social and Cultural Rights, Concluding observations on the sixth periodic report of Bulgaria, E/C.12/BGR/CO/6, 29 March 2019.

United Nations Committee on Economic, Social and Cultural Rights, List of issues in relation to the third periodic report of Slovakia. Addendum. Replies of Slovakia to the list of issues, E/C.12/SVK/Q/3/Add.1, 11 July 2019.

United Nations Committee on Economic, Social and Cultural Rights, Concluding observations on the third periodic report of Slovakia, E/C.12/SVK/CO/3, 14 November 2019.

United Nations Committee on the Elimination of Racial Discrimination, Concluding 
observations on the twentieth to twenty-second periodic reports of Greece, $\mathrm{CERD} / \mathrm{C} /$ GRC/CO/20-22, 3 October 2016.

United Nations Committee on the Elimination of Racial Discrimination, Concluding observations on the combined second to fifth periodic reports of Serbia, CERD/C/SRB/ CO/2-5, 3 January 2018.

United Nations Committee on the Elimination of Racial Discrimination, Concluding observations on the combined eleventh and twelfth periodic reports of Slovakia, CERD/C/SVK/CO/11-12, 12 January 2018.

European Court of Human Rights, Mižigárová v. Slovakia, app. no 74832/01, 14 December 2010. European Court of Human Rights, V.C. v. Slovakia, app. no. 18968/07, 8 November 2011. European Court of Human Rights, Koky and others v. Slovakia, app. no. 13624/03, 12 June 2012.

European Court of Human Rights, I.G. and others v. Slovakia, app. no. 15966/04, 13 November 2012.

European Court of Human Rights, Hudorovič and others v. Slovenia, app. nos. 24816/14 and 25140/14, 10 March 2020.

European Commission, Proposal for a Directive of the European Parliament and of the Council on the quality of water intended for human consumption (recast), $\operatorname{COM}(2017)$ 753 final (2018).

European Economic and Social Committee, Opinion of the European Economic and Social Committee on the Communication from the Commission on the European Citizens' Initiative Water and sanitation are a human right! Water is a public good, not a commodity! (COM(2014) 177 final) (own-initiative opinion) 2015 OJ C 12 (15 October 2014).

European Parliament, Resolution on the follow-up to the European Citizens' Initiative Right2Water, 2014/2239(INI) (8 September 2015).

\section{Documents of non-governmental organizations}

European Roma Rights Centre and Center for Civil and Human Rights (Poradña pre občianske a ludské práva), Written Comments of the European Roma Rights Centre and Center for Civil and Human Rights, Concerning Slovakia. [online]. Available at: $<$ https://tbinternet.ohchr.org/Treaties/CRC/Shared\%20Documents/SVK/INT_CRC_ NGO_SVK_23781_E.pdf $>$ accessed 5.9.2020.

European Roma Rights Centre and Forum for Human Rights, Written Comments of the European Roma Rights Centre and the Forum for Human Rights Concerning Slovakia For the Consideration of the United Nations Committee on the Elimination of Racial Discrimination to the 94th Session (20 November - 8 December 2017), [online]. Available at: <https://tbinternet.ohchr.org/Treaties/CERD/Shared\%20Documents/SVK/ INT_CERD_NGO_SVK_29438_E.pdf $>$ accessed 5.9.2020.

European Roma Rights Centre, Written comments by the European Roma Rights Centre for the consideration of the Committee on Economic, Social and Cultural Rights at its 62nd session, 3 April 2018 - 6 April 2018, [online]. Available at: <https://tbinternet.ohchr. org/_layouts/15/treatybodyexternal/Download.aspx?symbolno=INT\%2fCESCR\%2fI CO\%2fSVK\%2f29942\&Lang=en $>$ accessed 5.9.2020>.

Forum for Human Rights and Center for Civil and Human Rights (Poradňa pre občianske a ludské práva), NGOs information to the UN Committee on Economic, Social and Cultural Rights For Consideration when Compiling the Concluding Observations on the Third Periodic Report of the Slovak Republic under the International Covenant on Economic, Social and Cultural Rights, [online] Availble at: <https://tbinternet.ohchr.org/ 
Treaties/CESCR/Shared\%20Documents/SVK/INT_CESCR_CSS_SVK_35669_E. pdf $>$ accessed 5.9.2020.

\section{Miscellanea}

THOOMPAIL, Meera. Targeted COVID-19 testing in Roma settlements in Slovakia - A positive measure or further stigmatization?, [online]. Available at: $<$ https://minorityrights.org/2020/06/02/roma-slovakia-covid-testing/> accessed 11.11.2020.

BIKÁR, František. Slovakia's Romani settlements are very endangered by the COVID-19 pandemic, some have no access to potable water [online]. Available at: < http://www. romea.cz/en/news/world/slovakia-apos-s-romani-settlements-are-very-endangeredby-the-covid-19-pandemic-some-have-no-access-to-potable-water $>$ accessed 12.11.2020.

Ombudsperson of Slovakia. Správa o prieskume dodržiavania základných ludských práv a slobôd. Prístup k pitnej vode a informácia o zabezpečení protipožiarnej ochrany v rómskych osadách (Report on Survey of Compliance with Fundamental Human Rights and Freedoms. Access to Drinking Water. [online]. Available at: < https://www.vop.gov. sk/files/Pristup_k_vode.pdf>p. 19, accessed 14.10.2020.

Ministry of Interior of the Slovak Republic, Výzva zameraná na podporu prístupu k pitnej vode - OPLZ-PO6-SC611-2016-3 - uzavretá dňa 16. novembra 2018. [online]. Available at: $<$ http://www.minv.sk/?archiv-vyziev-3\&sprava=vyzva-zamerana-na-podporupristupu-k-pitnej-vode-oplz-po6-sc611-2016-3-uzavreta-dna-16-novembra-2018> accessed 30.10.2020.

Ministry of Interior of the Slovak Republic, Výzva zameraná na podporu prístupu k pitnej vode v prostredi $M R K, 2020$. [online]. Available at: < https://www.minv.sk/?aktualnevyzvy-na-predkladanie-ziadosti-o-nenavratny-financny-prispevok\&sprava=vyzvazamerana-na-podporu-pristupu-k-pitnej-vode-v-prostredi-mrk> accessed 30.10.2020.

Červenica municipality, Contract for work, 2018 [online]. Available at: <https://www.uvo. gov.sk/vyhladavanie-dokumentov/detail/3039797> accessed 1.11.2020.

Moldava nad Bodvou municipality, Contract for work, 2018 [online]. AVailable at: $<\mathrm{htt}-$ ps://egov.moldava.sk/FileOutputHttpHandler.ashx?arguments=CKgi\%2bQV\%2b2 WhY5kRLFEUAXWe\%2fTqmrN0E9QQ7fqsiZFxsfl6tGpR39PkirSFn82PljWxbOcST zqF8ahopVM0HwdvwY1F8UyuUudw\%3d\%3d>, accessed 1.11.2020.

Prakovce municipality, Contract for sale, 2019 [online]. Available at: <https://www.prakovce.sk/download_file_f.php?id=1162307> accessed 1.11.2020.

Rankovce municipality, Contract for work, 2019 [online]. Available at: $<$ https://www.obecrankovce.sk/download_file_f.php?id=1155880 > accessed 5.11.2020.

Spišský Štvrtok municipality, Annex no. 1 to the contract for work, 2017 [online]. Available at: <https://www.uvo.gov.sk/vyhladavanie-dokumentov/detail/914373>, accessed 5.11.2020. 